\title{
Evaluasi Efisiensi Produksi dengan Menggunakan Metode DEA Studi Kasus: Seluruh Unit Pabrik PTPN XI Tahun 2018
}

\author{
Febi Murdianti, dan Syarifa Hanoum \\ Departemen Manajemen Bisnis, Institut Teknologi Sepuluh Nopember (ITS) \\ e-mail: syarifa@mb.its.ac.id
}

\begin{abstract}
Abstrak-Industri berbasis tebu dalam negeri di masa kini menghadapi banyak tantangan perubahan. Pada periode tahun 2017-2018 Indonesia menjadi importir gula terbesar di dunia. Tingginya jumlah impor gula tersebut disebabkan oleh produksi nasional yang belum mencukupi kebutuhan nasional yang semakin meningkat. PT Perkebunan Nusantara XI adalah salah satu badan usaha milik negara (BUMN) yang bergerak di bidang agribisnis dengan core business yaitu memproduksi gula. Saat ini, PT Perkebunan Nusantara XI memiliki permasalahan yaitu menurunnya efisiensi produksi. Inefisiensi tersebut mengakibatkan produksi gula nasional tidak dapat memenuhi kebutuhan gula nasional. Penelitian ini dilakukan untuk mengevaluasi efisiensi produksi industri tebu di Indonesia, yaitu pada seluruh unit pabrik (13 unit pabrik) PT Perkebunan Nusantara XI pada tahun 2018. Metode yang digunakan adalah Data Envelopment Analysis (DEA) sebagai alat untuk melakukan pengukuran kinerja (efisiensi produksi). Berdasarkan hasil perhitungan technical efficiency (TECRs), terdapat 5 pabrik gula PT Perkebunan Nusantara XI yang mencapai tingkat efisiensi optimal. Berdasarkan hasil perhitungan technical efficiency (TEvrs), terdapat 10 pabrik gula PT Perkebunan Nusantara XI yang mencapai tingkat efisiensi optimal. Berdasarkan hasil perhitungan dan penentuan peer group didapatkan beberapa pabrik gula yang dijadikan sebagai referensi atau acuan, antara lain Pabrik Gula Pagottan, Panji, Prajekan, Wonolangan, dan Wringin Anom. Variabel yang berpengaruh signifikan terhadap inefisiensi pabrik gula PT Perkebunan Nusantara XI adalah variabel tenaga kerja, biaya listrik, dan kapasitas produksi.
\end{abstract}

Kata Kunci-Data Envelopment Analysis, Decision Making Unit, Efisiensi Produksi, Pabrik Gula, Pengukuran Kinerja.

\section{PENDAHULUAN}

I NDUSTRI berbasis tebu dalam negeri di masa kini menghadapi banyak tantangan perubahan. Pada tahun 1930an Indonesia pernah menjadi eksportir gula terbesar kedua di dunia dengan jumlah produksi 3 juta ton per tahun [1]. Namun, berdasarkan data dari Statista Indonesia menjadi importir gula terbesar di dunia pada periode tahun 2017-2018 dengan jumlah impor gula sebesar 4,45 juta ton [2]. Tingginya jumlah impor gula disebabkan oleh produksi nasional yang belum mencukupi kebutuhan konsumsi gula yang semakin meningkat [3]. Dalam lima tahun terakhir (2014-2018) jumlah kebutuhan gula nasional selalu meningkat tetapi jumlah produksi gula nasional selalu menurun [4]. Kendala utama yang dihadapi pabrik gula saat ini adalah rendahnya kualitas bahan baku, rendahnya kapasitas sebagian pabrik dan rendahnya efisiensi pabrik, tingginya jam berhenti serta tingginya biaya produksi [5].
PT Perkebunan Nusantara XI adalah salah satu badan usaha milik negara (BUMN) yang bergerak di bidang agribisnis dengan core business yaitu memproduksi atau mengolah gula yang berkontribusi sekitar 16-18\% terhadap produksi nasional [6]. PT Perkebunan Nusantara XI juga memiliki masalah yang terkait dengan menurunnya efisiensi produksi. Menurut Satrianegara kinerja PT Perkebunan Nusantara (PTPN) sangat jauh tertinggal dibandingkan dengan swasta [7]. Inefisiensi tersebut mengakibatkan produksi gula tidak dapat memenuhi kebutuhan dalam negeri. Pengukuran kinerja pada PT Perkebunan Nusantara XI dilakukan pada tiap divisi dengan berbagai kriteria pada masing-masing divisi, sehingga tidak dilakukan secara terpusat atau keseluruhan. Pengukuran efisiensi pada PT Perkebunan Nusantara XI terdiri dari pengukuran efisiensi gilingan dan efisiensi pabrik. Dengan metode pengukuran existing tersebut, maka tidak dapat diketahui secara keseluruhan faktor-faktor apa saja yang dapat menyebabkan terjadinya masalah inefisiensi. Dengan menggunakan metode Data Envelopment Analysis (DEA), maka pengukuran kinerja (efisiensi produksi) dapat dilakukan secara keseluruhan yang melibatkan berbagai komponen.

Pada penelitian ini akan dilakukan evaluasi efisiensi produksi yang dilakukan dengan menggunakan teknik linear programming yang disebut Data Envelopment Analysis (DEA) untuk mengukur efisiensi keseluruhan Decision Making Unit (DMU). Dengan hasil evaluasi efisiensi produksi yang telah didapatkan, kemudian dapat dilakukan berbagai langkah atau strategi perbaikan input atau sumber daya yang digunakan pada Decision Making Unit (DMU) yang masih kurang tingkat efisiensinya.

\section{LANDASAN TEORI}

\section{A. Pengukuran Kinerja Berbasis Efisiensi}

Efisiensi merupakan salah satu parameter kinerja yang mendasari seluruh kinerja suatau organisasi atau perusahaan [8]. Efisiensi adalah ukuran yang menunjukkan bagaimana baiknya sumber-sumber daya ekonomi dalam proses produksi untuk menghasilkan output. Sehingga dengan dilakukannya identifikasi alokasi input dan output, dapat dilakukan suatu analisa untuk mengetahui penyebab ketidakefisiensian. Efisiensi sebuah perusahaan terdiri dari dua komponen, yaitu technical efficiency dan allocative efficiency [9]. Sehingga 
dapat disimpulkan bahwa suatu organisasi dapat dikatakan efisien, jika output yang dihasilkan dapat ditingkatkan tanpa menambahkan atau meningkatkan input dan menurunkan output tertentu lainnya.

\section{B. Data Envelopment Analysis (DEA)}

Data Envelopment Analysis (DEA) adalah sebuah teknik pemrograman matematis berdasarkan pada linear programming yang digunakan untuk mengevaluasi efisiensi dari suatu unit pengambilan keputusan (unit kerja) yang bertanggung jawab menggunakan sejumlah input untuk memperoleh suatu output yang ditargetkan [10]. Secara sederhana, pengukuran ini dinyatakan dengan rasio output/input yang merupakan suatu pengukuran efisiensi atau produktivitas. DEA memungkinkan kita untuk menghitung keseluruhan cost efficiency (CE), technical efficiency (TE), allocative efficiency (AE), pure technical efficiency (PFE), dan scale efficiency (SE) [11]. Kemampuan DEA untuk mengidentifikasi unit yang digunakan sebagai referensi yang dapat membantu menentukan penyebab dan jalan keluar dari ketidakefisiensian. Dalam pengukuran efisiensi dengan menggunakan DEA terdapat dua model yang sering digunakan, yaitu:

\section{1) Constant Return to Scale (CRS)}

Model DEA yang pertama kali diperkenalkan berorientasi pada input berdasarkan asumsi constant return to scale sehingga dikenal dengan model CCR [12]. Dengan asumsi bahwa DMU beroperasi pada skala optimal. Untuk menentukan bobot optimal dilakukan dengan menggunakan pemrograman matematika sebagai berikut:

$$
\begin{gathered}
\text { Max } h_{n}=\sum_{j} u_{j} y_{j n} \\
\text { Subject to } \sum_{i} v_{i} x_{i n}=1 \\
\sum_{j} u_{j} y_{j n}-\sum_{i} v_{i} x_{i n} \leq 0 \\
u_{j, v_{i}} \geq \varepsilon
\end{gathered}
$$

Nilai efisiensi teknis dalam DEA tidak hanya mengidentifikasi unit yang tidak efisien, tapi juga derajat ketidakefisiensiannya. DEA memberikan estimasi target peningkatan efisiensi untuk DMUs yang tidak efisien berupa nilai peningkatan output yang secara matematis dirumuskan pada persamaan berikut:

$$
\begin{gathered}
x^{\prime}{ }_{\text {ino }}=x_{\text {ino }}-I S_{i} \\
y_{\text {ino }}^{\prime}=\theta^{*} y_{\text {jno }}+O S_{J}
\end{gathered}
$$

Sedangkan pendekatan lainnya, yaitu Input Oriented DEA memberikan target berupa nilai penurunan input.

\section{2) Variable Return to Scale (VRS)}

Model asumsi ini adalah variable return to scale yang artinya bahwa penambahan input sebesar $x$ kali tidak akan menyebabkan output meningkat sebesar x kali, bisa lebih kecil atau lebih besar. Variable return to scale menggambarkan technical efficiency secara keseluruhan yang terdiri dari dua komponen: pure technical efficiency dan scale efficiency.

\begin{tabular}{|c|c|c|}
\hline No & Unit & Alamat \\
\hline \multirow[t]{2}{*}{1.} & PG & $\begin{array}{llll}\text { Desa } & \text { Trigonco } & \text { Timur, } & \text { Assembagoes, }\end{array}$ \\
\hline & Assembagoes & Kabupaten Situbondo, Jawa Timur \\
\hline 2. & PG Djatiroto & $\begin{array}{l}\text { Desa Kaliboto, Jatiroto, Kabupaten L umajang, } \\
\text { Jawa Timur }\end{array}$ \\
\hline 3. & PG Gending & $\begin{array}{l}\text { Desa Sebaung, Gending, Kabupaten } \\
\text { Probolinggo, Jawa Timur }\end{array}$ \\
\hline 4. & PG Kanigoro & $\begin{array}{l}\text { Desa Sidorejo, Wungu, Kabupaten Madiun, } \\
\text { Jawa Timur }\end{array}$ \\
\hline 5. & PG Kedawoeng & $\begin{array}{l}\text { Desa Kedawoeng Kulon, Grati, Kabupaten } \\
\text { Pasuruan, Jawa Timur }\end{array}$ \\
\hline 6. & PG Padjarakan & $\begin{array}{l}\text { Desa Sukokerto, Probolinggo, Kabupaten } \\
\text { Pasuruan, Jawa Timur }\end{array}$ \\
\hline 7. & PG Pagottan & $\begin{array}{l}\text { Desa Pagottan, Geger, Kabupaten Madiun, } \\
\text { Jawa Timur }\end{array}$ \\
\hline 8. & PG Purwodadie & $\begin{array}{l}\text { Desa Palem, Karangrejo, Kabupaten Magetan, } \\
\text { Jawa Timur }\end{array}$ \\
\hline 9. & PG Prajekan & $\begin{array}{l}\text { Desa Rajekan Kidul, Prajekan, Kabupaten } \\
\text { Bondowoso, Jawa Timur }\end{array}$ \\
\hline 10. & PG Redjosari & $\begin{array}{l}\text { Desa Redjosarie, Kawedanan, Kabupaten } \\
\text { Magetan, Jawa Timur }\end{array}$ \\
\hline 11. & PG Semboro & $\begin{array}{l}\text { Desa/Kecataman Semboro, Kabupaten Jember, } \\
\text { Jawa Timur }\end{array}$ \\
\hline 12. & PG Soedono & $\begin{array}{l}\text { Desa Tepas, Geneng, Kabupaten Ngawi, Jawa } \\
\text { Timur }\end{array}$ \\
\hline 13. & PG & Desa Kedawoeng Dalem, Dringu, Kabupaten \\
\hline & langan & Probolinggo, Jawa Timur \\
\hline
\end{tabular}
Program linier DEA-CRS dapat dengan mudah dimodifikasi kedalam model DEA-VRS dengan menambahkan pembatas konveksitas (convexity constraints) pada persamaan berikut:
Tabel 1.

Unit PT Perkebunan Nusantara XI (13 unit pabrik)

$$
\sum_{n} \lambda_{n}=1
$$

Penggunaan spesifikasi CRS dimana DMUs sebenarnya tidak beroperasi pada skala optimal, akan mengakibatkan ukuran technical efficiency (TE) dikalahkan oleh scale efficiency (SE). Dengan kata lain, nilai technical efficiency (TE) yang diperoleh dari formulasi DEA-CRS (TE $\left.E_{C R S}\right)$ dapat didekomposisikan ke dalam dua komponen, yaitu: 'pure' technical efficiency $\left(T E_{V R S}\right)$ dan scale efficiency (SE).

$$
S E=\frac{T E_{C R S}}{T E_{V R S}}
$$

\section{METODOLOGI PENELITIAN}

\section{A. Subyek dan Obyek Penelitian}

Subjek penelitian ini adalah PT Perkebunan Nusantara XI . Sedangkan objek dari penelitian ini adalah seluruh unit (13 unit pabrik) di PT Perkebunan Nusantara XI. Sehingga penelitian ini menggunakan data dari seluruh unit (13unit pabrik) di PT Perkebunan Nusantara XI yang dapat dilihat pada Tabel 1.

\section{B. Metodologi dan Tahapan Penelitian}

Terdapat 5 tahap utama yang akan dilakukan dalam penelitian ini yang terdiri dari tahap persiapan, spesifikasi model, pengumpulan data, implementasi model, dan tahap akhir.

\section{1) Tahap Persiapan}

a. Identifikasi kondisi existing perusahaan terkait visi misi, proses bisnis, pengukuran kinerja, pengukuran efisiensi PT Perkebunan Nusantara XI.

Hal tersebut digunakan sebagai salah satu dasar untuk menentukan fungsi tujuan dalam formulasi model Data Envelopment Analysis (DEA). 
b. Identifikasi rumusan penelitian terkait evaluasi efisiensi produksi pada seluruh unit pabrik di PT Perkebunan Nusantara XI.

Yang dimana valuasi efisiensi produksi dilakukan secara menyuluruh pada serangkaian proses bisnis yang dilakukan pada setiap unit pabrik. Dimulai dari tahap perolehan bahan baku, pengolahan, hingga produk jadi (gula kristal). Sehingga akan diketahui unit pabrik (Decision Making unit/DMU) yang efisien dan inefisien beserta strategi rekomendasi untuk peningkatan efisiensinya

c. Melakukan studi literatur terkait penelitian terdahulu tentang pengukuran atau penilaian efisiensi produksi pada industri gula dengan menggunakan Data Envelopment Analysis (DEA) dan melakukan analisa perbandingan atau perbedaan antara penelitian terdahulu dengan penelitian yang akan dilakukan.

2) Spesifikasi Model

Berikut akan dibahas mengenai spesifikasi model yang digunakan pada penelitian, terdiri dari empat tahapan yaitu sebagai berikut:

a. Identifikasi unit pabrik (Decision Making unit/DMU) yang akan dilakukan evaluasi efisiensi produksi.

Dihasilkan 13 unit pabrik (Decision Making Unit/DMU) yang masih beroperasi atau melakukan produksi gula kristal dan selanjutnya untuk dilakukan evaluasi efisiensi produksi.

b. Penentuan fungsi tujuan yang ingin dicapai perusahaan

Tujuan yang ingin dicapai perusahaan yaitu Output oriented-DEA yang mengukur efisiensi teknis sebagai peningkatan proporsional output.

c. Penentuan variabel input dan output

Variabel Input yang digunakan yaitu Luas lahan (X1), Jumlah tebu giling (X2), Kapasitas produksi (X3), Biaya listrik (X4), dan Jumlah tenaga kerja (X5). Variabel Output yang digunakan yaitu Jumlah produksi gula kristal (Y1).

d. Menyusun model matematis atau formulasi metode Data Enevelopment Analysis (DEA).

\section{3) Pengumpulan Data}

Peneliti melakukan pengumpulan data untuk penelitian ini mulai April hingga Mei 2019 di Kantor Pusat PT Perkebunan Nusantara XI Kota Surabaya. Teknis pengumpulan datanya yaitu formulir pengumpulan data diberikan pada Kadiv atau staff di masing-masing divisi yang terdiri dari Divisi Sumber Daya Manusia, Tanaman, Pengolahan, dan Teknik. Kemudian staff divisi tersebut akan mengisi data yang dibutuhkan dan mengirinkan data berupa softfile ke email peneliti.

\section{4) Implementasi Model}

Tahapan yang keempat adalah implementasi model. Dalam implementasi model ini terdapat berbagai proses yang dilakukan, terdiri dari formulasi model matematis DEA, perhitungan efisiensi relatif, analisis variabel DEA, analisa dan pembahasan (Penentuan unit pabrik/Decision Making Unit yang efisien dan tidak efisien, serta pemberian rekomendasi perbaikan untuk yang tidak efisien). Pemberian strategi rekomendasi pada tahap ini dilakukan berdasarkan hasil dari pengolahan data dan analisis.

\section{5) Formulasi Model Matematis DEA}

Penelitian ini menggunakan dua model DEA yaitu Model CRS dan Model VRS Output Oriented.

a. Technical Efficiency (TE)

Nilai efisiensi atau technical efficiency (TE) dihitung dengan model matematis DEA berdasarkan constant return to scale $\left(\mathrm{TE}_{\mathrm{CRS}}\right)$, berupa nilai efisiensi teknik $=1$ jika DMUs tersebut efisien, dan $<1$ jika tidak efisien, sehingga dapat ditentukan unit pabrik yang efisien dan tidak efisien. Struktur formulasi matematisnya dapat dilihat pada persamaan berikut:

Fungsi Obyektif :

$$
\operatorname{Max}: \theta_{n}+\varepsilon\left(\sum_{i} S_{i}+\sum_{j} O S_{j}\right)
$$

Constraints (Fungsi Pembatas):

Output 1 : Jumlah produksi

$$
\sum_{n} y_{1 n} \lambda_{n}-\theta_{n} y_{1 o}-O S_{1}=0
$$

Input 1: Jumlah tebu giling

$$
\sum_{n} x_{1 n} \lambda_{n}+I S_{1}=x_{1 o}
$$

Input 2: Jumlah tenaga kerja

$$
\sum_{n} x_{2 n} \lambda_{n}+I S_{2}=x_{2 o}
$$

Input 3: Biaya bahan bakar

$$
\sum_{n} x_{3 n} \lambda_{n}+I S_{3}=x_{3 o}
$$

Input 4: Kapasitas giling

Input 5: Luas lahan

$$
\sum_{n} x_{4 n} \lambda_{n}+I S_{4}=x_{4 o}
$$

Keterangan Indeks:

$$
\sum_{n} x_{5 n} \lambda_{n}+I S_{5}=x_{5 o}
$$

$n=$ DMUs, $n=1, . ., 13$

$j=$ output $, \quad j=1, . ., 2$

$i=$ input, $\quad i=1, . ., 5$

Keterangan Data :

$y_{j n} \quad=$ nilai dari output ke- $j$ dari DMU ke $n$

$x_{i n}=$ nilai dari input ke- $i$ dari DMU ke $n$

$\varepsilon \quad=$ angka positif yang kecil $\left(10^{-6}\right)$

$y_{j o}$ dan $x_{i o}=$ nilai output dan input DMU yang sedang diobservasi.

Keterangan Variabel :

$\theta_{n} \quad=$ efisiensi relatif $\mathrm{DMU}_{\mathrm{n}}$

$I S_{i}, O S_{j}=$ slack dari input $i$, output $j(\geq 0)$

$\lambda_{n} \quad=$ bobot DMUn $(\geq 0)$ thd DMU yg dievaluasi

b. Scale Efficiency (SE)

CRS Dual dan VRS digunakan untuk mencari nilai Scale Efficiency. Perbedaan output efisiensi teknis $\mathrm{TE}_{\mathrm{CRS}}$ dan TE $\mathrm{VRS}_{\mathrm{V}}$ menunjukkan nilai scale efficiency (SE). Apabila nilai $\mathrm{TE}_{\mathrm{CRS}}$ sama dengan nilai TEVRs maka nilai SE akan sama dengan satu. Namun jika nilai SE lebih dari satu, hal itu merupakan indikasi bahwa DMU tersebut mempunyai scale inefficiency.

Apabila $\mathrm{TE}_{\mathrm{VRS}}>\mathrm{SE}$ maka perubahan efisiensi (baik peningkatan maupun penurunan) dipengaruhi oleh efisiensi teknis murni. Namun, apabila TEVRs $<$ SE maka perubahan efisiensi lebih disebabkan oleh perkembangan scale efficiency. Perhitungan ini dilakukan dengan menggunakan software MaxDEA 7 Basic.

c. Analisa Variabel DEA

Analisa variabel dengan metode DEA diperlukan untuk mengetahui nilai bobot yang diberikan model terhadap tiap variabel. Model yang dimaksud adalah model DEA CRS 
Tabel 4. Nilai Efisiensi CRS DEA-Output Oriented

\begin{tabular}{ccc}
\hline \hline No & DMU & 2018 \\
\hline 1 & Gending & 0.917297 \\
2 & Jatiroto & 0.961858 \\
3 & Kedawung & 0.92708 \\
4 & Olean & 0.823117 \\
5 & Pagottan & 1 \\
6 & Panji & 1 \\
7 & Prajekan & 1 \\
8 & Purwodadie & 0.896788 \\
9 & Rejosari & 0.859419 \\
10 & Semboro & 0.991946 \\
11 & Sudhono & 0.856087 \\
12 & Wonolangan & 1 \\
13 & Wringin Anom & 1 \\
\hline \hline
\end{tabular}

Tabel 5.

Nilai Efisiensi VRS DEA-Output Oriented

\begin{tabular}{|c|c|c|}
\hline No & DMU & 2018 \\
\hline 1 & Gending & 1 \\
\hline 2 & Jatiroto & 1 \\
\hline 3 & Kedawung & 1 \\
\hline 4 & Olean & 1 \\
\hline 5 & Pagottan & 1 \\
\hline 6 & Panji & 1 \\
\hline 7 & Prajekan & 1 \\
\hline 8 & Purwodadie & 0.96403 \\
\hline 9 & Rejosari & 0.941185 \\
\hline 10 & Semboro & 1 \\
\hline 11 & Sudhono & 0.926336 \\
\hline 12 & Wonolangan & 1 \\
\hline 13 & Wringin Anom & 1 \\
\hline
\end{tabular}

Grafik Bobot Kontribusi Pabrik Gula Sebagai Peer Group 2018

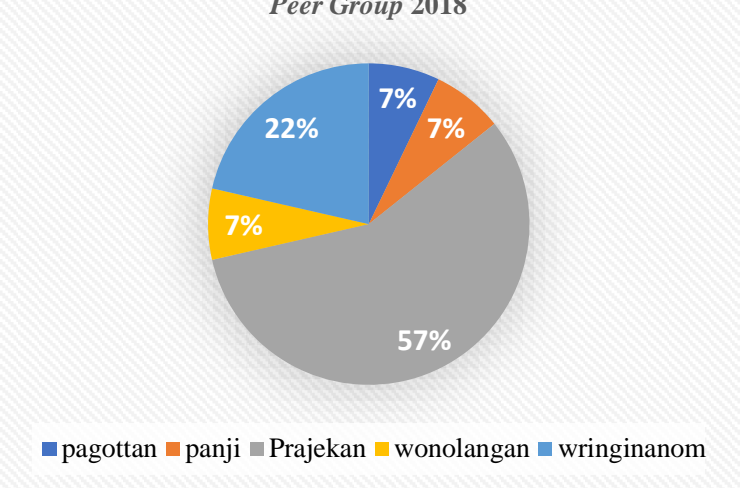

Gambar 1. Grafik Bobot Peer Group CRS 2018

Primal yaitu model model DEA yang memiliki performansi secara lengkap. Variasi besar bobot yang diterima oleh tiap periode di bagian produksi menunjukkan bahwa setiap variabel memberikan kontribusi yang berbeda, artinya jika variabel mendapatkan nilai bobot terbesar hal ini menunjukkan bahwa variabel tersebut lebih berpengaruh pada pengambilan keputusan. Sedangkan variabel yang memiliki bobot nilai yang kecil memiliki pengaruh yang kecil pula terhadap pengambilan keputusan pada setiap periode di bagian produksi.

d. Penentuan DMU yang Efisien dan Inefisien

Setelah dilakukan perhitungan efisiensi teknik yang menggunakan model DEA CRS Primal, maka akan diketahui
Tabel 2.

Nilai Scale Efficiency (SE)

\begin{tabular}{clcc}
\hline \hline \multirow{2}{*}{ No } & \multirow{2}{*}{ DMU } & \multicolumn{2}{c}{2018} \\
\cline { 3 - 4 } & & Scale Efficiency Score & Return to Scale (RTS) \\
\hline 1 & Gending & 0.917297 & Increasing \\
2 & Jatiroto & 0.961858 & Decreasing \\
3 & Kedawung & 0.92708 & Increasing \\
4 & Olean & 0.823117 & Increasing \\
5 & Pagottan & 1 & Constant \\
6 & Panji & 1 & Constant \\
7 & Prajekan & 1 & Constant \\
8 & Purwodadie & 0.930249 & Increasing \\
9 & Rejosari & 0.913125 & Increasing \\
10 & Semboro & 0.991946 & Decreasing \\
11 & Sudhono & 0.924164 & Increasing \\
12 & Wonolangan & 1 & Constant \\
13 & Wringin Anom & 1 & Constant \\
\hline \hline
\end{tabular}

Tabel 3.

Peer Group CRS DEA Output Oriented

\begin{tabular}{|c|c|c|c|}
\hline $\mathrm{NO}$ & DMU & Score & Benchmark(Lambda) \\
\hline 1 & Gending & 0,92 & $\begin{array}{l}\text { Prajekan }(0,392880) ; \text { Wringin Anom } \\
(0,156953)\end{array}$ \\
\hline 2 & Jatiroto & 0,96 & Prajekan $(1,423894) ;$ Wonolangan \\
\hline & & & $\begin{array}{l}(0,276678) ; \\
(0,718647)\end{array} \quad$ Wringin $\quad$ Anom \\
\hline 3 & Kedawung & 0,93 & $\begin{array}{l}\text { Pagottan } \quad(0,037254) ; \quad \text { Panji } \\
(0,163046) \text {; Prajekan }(0,248828)\end{array}$ \\
\hline 4 & Olean & 0,82 & Prajekan $(0,338036)$ \\
\hline 5 & Pagottan & 1,00 & Pagottan $(1,000000)$ \\
\hline 6 & Panji & 1,00 & Panji $(1,000000)$ \\
\hline 7 & Prajekan & 1,00 & Prajekan $(1,000000)$ \\
\hline 8 & Purwodadie & 0,90 & Prajekan $(0,564269)$ \\
\hline 9 & Rejosari & 0,86 & Prajekan $(0,509738)$ \\
\hline 10 & Semboro & 0,99 & $\begin{array}{l}\text { Prajekan }(1,436902) \text {; Wringin Anom } \\
(1,276084)\end{array}$ \\
\hline 11 & Sudhono & 0,86 & Prajekan $(0,543603)$ \\
\hline 12 & Wonolangan & 1,00 & Wonolangan $(1,000000)$ \\
\hline 13 & Wringin Anom & 1,00 & Wringin Anom $(1,000000)$ \\
\hline
\end{tabular}

DMU - DMU mana yang dianggap efisien maupun yang inefisien.

\section{e. Penentuan Peer Group}

Peer Group merupakan pengelompokkan unit yang efisien dengan unit yang tidak efisien, sehingga dapat memberikan arahan perbaikan bagi unit yang tidak efisien. Peer Group ini dibentuk untuk menentukan arahan perbaikan efisiensi bagi DMU yang inefisien dan sebagai salah satu teknik perbaikan dari DEA. Penentuan Peer Group ini dilakukan dengan menggunakan software MaxDEA 7 Basic.

\section{ANALISIS DAN DISKUSI}

\section{A. Perhitungan Efisiensi CRS DEA-Output Oriented}

Berikut adalah hasil perhitungan dan analisa Efisiensi CRS DEA-Output Oriented. Berdasarkan nilai Technical Efficiency ( $\mathrm{TE}_{\mathrm{CRS}}$ ) pada Tabel 2, dapat diketahui pada tahun 2018 terdapat 5 pabrik gula PT Perkebunan Nusantara XI yang mencapai tingkat efisiensi optimal (nilai efisiensi 1) terdiri dari Pabrik Gula Pagottan, Panji, Prajekan, Wonolangan, dan Wringin Anom.

\section{B. Perhitungan Efisiensi VRS DEA-Output Oriented}

Berikut adalah hasil perhitungan dan analisa Efisiensi VRS DEA-Output Oriented. Berdasarkan nilai Technical Efficiency 


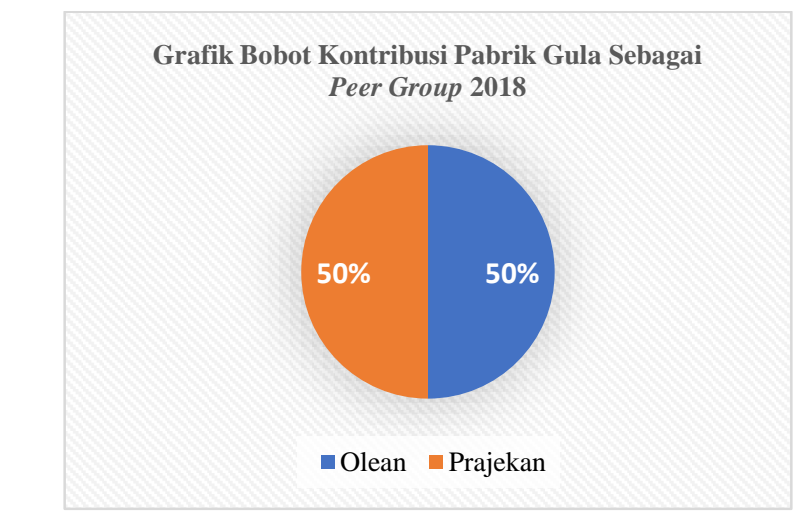

Gambar 2. Grafik Bobot Peer Group VRS 2018

Tabel 8.

Target Perbaikan Pabrik Gula Gending

\begin{tabular}{lccccc}
\hline \hline Variabel & Actual & $\begin{array}{c}\text { Pro- } \\
\text { portionate }\end{array}$ & Slack & Target & Improve \\
\hline $\begin{array}{l}\text { Luas } \\
\text { Lahan }\end{array}$ & 2622 & 0 & 0 & 2622 & $0 \%$ \\
$\begin{array}{l}\text { Tebu } \\
\text { Giling }\end{array}$ & 185619 & 0 & 0 & 185619 & $0 \%$ \\
$\begin{array}{l}\text { Kapasitas } \\
\text { Produksi }\end{array}$ & 1369 & 0 & -64 & 1305 & $5 \%$ \\
PLN & 1521080 & 0 & -98632 & 1422448 & $7 \%$ \\
Tenaga & 648 & 0 & -172 & 476 & $36 \%$ \\
Kerja & & 0 & 0 & 15525 & $8 \%$ \\
\hline Produksi & 14241 & 1284 & & & \\
\hline \hline
\end{tabular}

Tabel 9.

Target Perbaikan Pabrik Gula Jatiroto

\begin{tabular}{|c|c|c|c|c|c|}
\hline Variabel & Actual & $\begin{array}{c}\text { Pro- } \\
\text { portionate }\end{array}$ & Slack & Target & Improve \\
\hline $\begin{array}{l}\text { Luas } \\
\text { Lahan }\end{array}$ & 10551 & 0 & 0 & 10551 & $0 \%$ \\
\hline $\begin{array}{l}\text { Tebu } \\
\text { Giling }\end{array}$ & 762478 & 0 & 0 & 762478 & $0 \%$ \\
\hline $\begin{array}{l}\text { Kapasitas } \\
\text { Produksi }\end{array}$ & 6010 & 0 & -642 & 5368 & $12 \%$ \\
\hline PLN & 5995098 & 0 & 0 & 5995098 & $0 \%$ \\
\hline $\begin{array}{l}\text { Tenaga } \\
\text { Kerja }\end{array}$ & 2781 & 0 & -767 & 2014 & $38 \%$ \\
\hline Produksi & 60785 & 2410 & 0 & 63195 & $4 \%$ \\
\hline
\end{tabular}

(TEVRs), pada Tabel 3, dapat diketahui bahwa pada tahun 2018 terdapat 10 pabrik gula PT Perkebunan Nusantara XI yang mencapai tingkat efisiensi optimal (nilai efisiensi 1) terdiri dari Pabrik Gula Gending, Jatiroto, Kedawung, Olean, Pagottan, Panji, Prajekan, Semboro, Wonolangan, dan Wringin Anom.

\section{Perhitungan Scale Efficiency (SE)}

Berikut adalah hasil perhitungan dan analisa Scale Efficiency (SE). Berdasarkan hasil perhitungan Scale Efficiency (SE) pada Tabel 4, dapat diketahui bahwa pada tahun 2018 terdapat 2 pabrik gula yang beroperasi pada skala decreasing yaitu Pabrik Gula Jatiroto dan Semboro. Untuk DMU (pabrik gula) yang beroperasi pada skala increasing sebanyak 6 pabrik gula yang terdiri dari Pabrik Gula Gending, Kedawung, Olean, Purwodadi, Rejosari, Sudhono. Sedangkan pabrik gula yang beroperasi pada skala constant sebanyak 5 DMU (pabrik gula) yang terdiri dari Pabrik Gula Pagottan, Panji, Prajekan, Wonolangan, dan Wringin Anom.
Tabel 6.

Target Perbaikan Pabrik Gula Kedawung

\begin{tabular}{|c|c|c|c|c|c|}
\hline Variabel & Actual & $\begin{array}{c}\text { Pro- } \\
\text { portionate }\end{array}$ & Slack & Target & Improve \\
\hline $\begin{array}{l}\text { Luas } \\
\text { Lahan }\end{array}$ & 2243 & 0 & 0 & 2243 & $0 \%$ \\
\hline $\begin{array}{l}\text { Tebu } \\
\text { Giling }\end{array}$ & 161538 & 0 & -8842 & 152696 & $6 \%$ \\
\hline $\begin{array}{l}\text { Kapasitas } \\
\text { Produksi }\end{array}$ & 1827 & 0 & -713 & 1114 & $64 \%$ \\
\hline PLN & 807808 & 0 & 0 & 807808 & $0 \%$ \\
\hline $\begin{array}{l}\text { Tenaga } \\
\text { Kerja }\end{array}$ & 418 & 0 & 0 & 418 & $0 \%$ \\
\hline Produksi & 11634 & 915 & 0 & 12549 & $7 \%$ \\
\hline
\end{tabular}

Tabel 7.

Target Perbaikan Pabrik Gula Olean

\begin{tabular}{lccccc}
\hline \hline Variabel & Actual & $\begin{array}{c}\text { Pro- } \\
\text { portionate }\end{array}$ & Slack & Target & Improve \\
\hline $\begin{array}{l}\text { Luas } \\
\text { Lahan }\end{array}$ & 2032 & 0 & -7 & 2026 & $0,03 \%$ \\
Tebu & 134766 & 0 & 0 & 134766 & $0 \%$ \\
$\begin{array}{l}\text { Giling } \\
\text { Kapasitas }\end{array}$ & 1054 & 0 & -79 & 975 & $8 \%$ \\
$\begin{array}{l}\text { Produksi } \\
\text { PLN }\end{array}$ & 2164656 & 0 & -1372710 & 791946 & $173 \%$ \\
Tenaga & 672 & 0 & -352 & 320 & $110 \%$ \\
Kerja & 9510 & 2044 & 0 & 11554 & $18 \%$ \\
Produksi & & & & & \\
\hline \hline
\end{tabular}

\section{Hasil Penentuan Peer Group CRS DEA Output Oriented}

Berikut adalah hasil penentuan peer group CRS DEA-Output Oriented. Berdasarkan Tabel 5 terkait hasil peer group CRS tahun 2018 menunjukkan bahwa terdapat 5 pabrik gula yang menjadi acuan untuk masing-masing pabrik gula yang inefisien, yaitu Pabrik Gula Panji, Pabrik Gula Pagottan, Pabrik Gula Prajekan, Pabrik Gula Wonolangan, dan Pabrik Gula Wringin Anom.

\section{E. Analisis Peer Group CRS Output Oriented}

Pabrik gula yang menjadi referensi atau acuan antara lain Pabrik Gula Pagottan, Panji, Prajekan, Wonolangan, dan Wringin Anom. Berdasarkan grafik bobot kontribusi pabrik gula sebagai peer group 2018 pada Gambar 1, dapat diketahui bahwa presentase bobot peer group tertinggi dimiliki oleh Pabrik Gula Wonolangan dengan prosentase sebesar $57 \%$. Dimana pabrik gula tersebut memiliki frekuensi sebagai DMU referensi atau acauan untuk pabrik gula yang inefisien sebanyak 8 kali. Sedangkan bahwa presentase bobot peer group terendah dimiliki oleh Pabrik Gula Pagottan, Panji, dan Wonolangan dengan prosentase $7 \%$. Yang dimana pabrik gula tersebut memiliki frekuensi sebagai DMU referensi atau acauan untuk pabrik gula yang inefisien hanya 1 kali.

\section{F. Analisis Peer Groups VRS 2018}

Pabrik gula yang menjadi referensi atau acuan antara lain Pabrik Gula Prajekan dan Olean. Berdasarkan grafik bobot kontribusi pabrik gula sebagai peer group 2018 pada Gambar 2, dapat diketahui bahwa presentase bobot peer group tertinggi dimiliki oleh Pabrik Gula Prajekan dan Olean dengan prosentase sebesar 50\%. Yang dimana pabrik gula tersebut memiliki frekuensi sebagai DMU referensi atau acauan untuk pabrik gula yang inefisien sebanyak 8 kali. Sedangkan bahwa 
Tabel 10.

Target Perbaikan Pabrik Gula Purwodadi

\begin{tabular}{cccccc}
\hline \hline Variabel & Actual & $\begin{array}{c}\text { Pro- } \\
\text { portionate }\end{array}$ & Slack & Target & $\begin{array}{c}\text { Im- } \\
\text { prove }\end{array}$ \\
\hline $\begin{array}{c}\text { Luas } \\
\text { Lahan }\end{array}$ & 3868 & 0 & -487 & 3381 & $14 \%$ \\
Tebu & 224959 & 0 & 0 & 224959 & $0 \%$ \\
$\begin{array}{c}\text { Giling } \\
\text { Kapasitas }\end{array}$ & 2093 & 0 & -466 & 1627 & $29 \%$ \\
Produksi & & 0 & -1875560 & 1321960 & $142 \%$ \\
PLN & 3197520 & 0 & -592 & 535 & $111 \%$ \\
Tenaga & 1127 & 0 & 0 & 19286 & $10 \%$ \\
Kerja & 17296 & 1991 & & & \\
Produksi &
\end{tabular}

Tabel 11.

Target Perbaikan Pabrik Gula Rejosari

\begin{tabular}{cccccc}
\hline \hline Variabel & Actual & $\begin{array}{c}\text { Pro- } \\
\text { portionate }\end{array}$ & Slack & Target & $\begin{array}{c}\text { Im- } \\
\text { prove }\end{array}$ \\
\hline $\begin{array}{c}\text { Luas } \\
\text { Lahan }\end{array}$ & 3275 & 0 & -220 & 3054 & $7 \%$ \\
Tebu & 203219 & 0 & 0 & 203219 & $0 \%$ \\
$\begin{array}{c}\text { Giling } \\
\text { Kapasitas }\end{array}$ & 2409 & 0 & -938 & 1470 & $64 \%$ \\
Produksi & & 0 & -1059033 & 1194207 & $89 \%$ \\
PLN & 2253240 & 0 & -598 & 483 & $124 \%$ \\
Tenaga & 1081 & 0 & 0 & 17422 & $14 \%$ \\
Kerja & 14973 & 2449 & & & \\
Produksi & 149
\end{tabular}

Tabel 12.

Target Perbaikan Pabrik Gula Semboro

\begin{tabular}{cccccc}
\hline \hline Variabel & Actual & $\begin{array}{c}\text { Pro- } \\
\text { portionate }\end{array}$ & Slack & Target & Improve \\
\hline $\begin{array}{c}\text { Luas } \\
\text { Lahan }\end{array}$ & 12126 & 0 & -1341 & 10784 & $12 \%$ \\
Tebu & 817749 & 0 & -9210 & 808539 & $1 \%$ \\
Giling & & 0 & 0 & 5544 & $0 \%$ \\
Kapasitas & 5544 & 0 & 0 & 7447920 & $0 \%$ \\
Produksi & & 0 & -307 & 2206 & $14 \%$ \\
PLN & 7447920 & 0 & 0 & 66159 & $1 \%$ \\
Tenaga & 2513 & 533 & & & \\
Kerja & 65627 & & &
\end{tabular}

presentase bobot peer group terendah dimiliki oleh Pabrik Gula Pagottan, Panji, dan Wonolangan dengan prosentase 7\%. Yang dimana pabrik gula tersebut memiliki frekuensi sebagai DMU referensi atau acauan untuk pabrik gula yang inefisien sebanyak 3 kali.

\section{G. Target Perbaikan CRS 2018}

Dengan menggunakan metode DEA, maka didapatkan target perbaikan untuk DMU (pabrik gula) yang inefisien. Masingmasing pabrik gula akan mendapatkan dua pilihan target perbaikan untuk peningkatan efisiensinya. Berikut akan dibahas mengenai target perbaikan pada masing-masing pabrik gula yang inefisien.

\section{1) Pabrik Gula Gending}

Target perbaikan untuk Pabrik Gula Gending dapat dilihat pada Tabel 6. Pada tahun 2018 nilai efisiensi produksi yang dicapai Pabrik Gula Gending sebesar 0,92. Pabrik gula tersebut mengalami inefisiensi pada input kapasitas produksi, biaya listrik, dan tenaga kerja. Berdasarkan hasil perhitungan target perbaikan, untuk dapat mencapai efisiensi yang optimal, Pabrik Gula Gending harus mengurangi jumlah kapasitas produksi sebesar 64 ton, mengurangi jumlah input biaya listrik sebesar $98.632 \mathrm{kWh}$, dan mengurangi jumlah tenaga kerja sebanyak 172 orang. Dengan demikian, jumlah produksi Pabrik Gula Gending juga dapat meningkat sebanyak 1.284 ton dari jumlah produksi yang telah dikeluarkan pada tahun ini sebanyak 14.241 ton, sehingga target jumlah produksi yang diharapkan sebesar 15.525.

\section{2) Pabrik Gula Jatiroto}

Target perbaikan untuk Pabrik Gula Jatiroto dapat dilihat pada Tabel 7. Pada tahun 2018 nilai efisiensi produksi yang dicapai Pabrik Gula Jatiroto sebesar 0,96. Pabrik gula tersebut mengalami inefisiensi pada input kapasitas produksi, dan tenaga kerja. Berdasarkan hasil perhitungan target perbaikan, untuk dapat mencapai efisiensi yang optimal, Pabrik Gula Jatioroto harus mengurangi kapasitas produksi sebesar 642 ton, dan mengurangi jumlah tenaga kerja sebanyak 767 . Dengan demikian, jumlah produksi Pabrik Gula Jatiroto juga dapat meningkat sebanyak 2.410 ton dari jumlah produksi yang telah dikeluarkan pada tahun ini sebanyak 60.785 ton, sehingga target jumlah produksi yang diharapkan sebesar 61.395 ton.

\section{3) Pabrik Gula Kedawung}

Target perbaikan untuk Pabrik Gula Kedawung dapat dilihat pada Tabel 8. Pada tahun 2018 nilai efisiensi produksi yang dicapai Pabrik Gula Kedawung sebesar 0,93. Pabrik gula tersebut mengalami inefisiensi pada input tebu giling dan kapasitas produksi. Berdasarkan hasil perhitungan target perbaikan, untuk dapat mencapai efisiensi yang optimal, Pabrik Gula Kedawung harus mengurangi jumlah tebu giling sebanyak 8.842 ton, dan mengurangi kapasitas produksi sebesar 713 ton. Dengan demikian, jumlah produksi Pabrik Gula Kedawung juga dapat meningkat sebanyak 915 ton dari jumlah produksi yang telah dikeluarkan pada tahun ini sebanyak 11.634 ton, sehingga target jumlah produksi yang diharapkan sebesar 12.549 ton.

\section{4) Pabrik Gula Olean}

Target perbaikan untuk Pabrik Gula Gending dapat dilihat pada Tabel 9. Pada tahun 2018 nilai efisiensi produksi yang dicapai Pabrik Gula Olean sebesar 0,82. Pabrik gula tersebut mengalami inefisiensi pada input luas lahan, kapasitas produksi, biaya listrik, dan tenaga kerja. Berdasarkan hasil perhitungan target perbaikan, untuk dapat mencapai efisiensi yang optimal, Pabrik Gula Olean harus mengurangi luas lahan sebesar 7 ha, mengurangi kapasitas produksi sebesar 79 ton, mengurangi penggunaan listrik (biaya listrik) sebanyak $1.372 .710 \mathrm{kWh}$, dan mengurangi jumlah tenaga kerja sebanyak 352 orang. Dengan demikian, jumlah produksi Pabrik Gula Olean juga dapat meningkat sebanyak 2.044 ton dari jumlah produksi yang telah dikeluarkan pada tahun ini sebanyak 9.510 ton, sehingga target jumlah produksi yang diharapkan sebesar 11.554 ton.

\section{5) Pabrik Gula Purwodadi}

Target perbaikan untuk Pabrik Gula Gending dapat dilihat pada Tabel 10. Pada tahun 2018 nilai efisiensi produksi yang dicapai Pabrik Gula Purwodadi sebesar 0,90. Pabrik gula tersebut mengalami inefisiensi pada input luas lahan, kapasitas produksi, biaya listrik, dan tenaga kerja. Berdasarkan hasil perhitungan target perbaikan, untuk dapat mencapai efisiensi 
Tabel 13.

Target Perbaikan Pabrik Gula Sudhono

\begin{tabular}{cccccc}
\hline \hline Variabel & Actual & $\begin{array}{c}\text { Pro- } \\
\text { portionate }\end{array}$ & Slack & Target & $\begin{array}{c}\text { Im- } \\
\text { prove }\end{array}$ \\
\hline $\begin{array}{c}\text { Luas } \\
\text { Lahan }\end{array}$ & 3885 & 0 & -628 & 3257 & $19 \%$ \\
Tebu & 216720 & 0 & 0 & 216720 & $0 \%$ \\
$\begin{array}{c}\text { Giling } \\
\text { Kapasitas }\end{array}$ & 2402 & 0 & -834 & 1568 & $53 \%$ \\
Produksi & & 0 & -1189807 & 1273544 & $93 \%$ \\
PLN & 2463351 & 0 & -585 & 515 & $113 \%$ \\
Tenaga & 1100 & 0 & 0 & 18580 & $14 \%$ \\
Kerja & 15906 & 2674 & & & \\
Produksi &
\end{tabular}

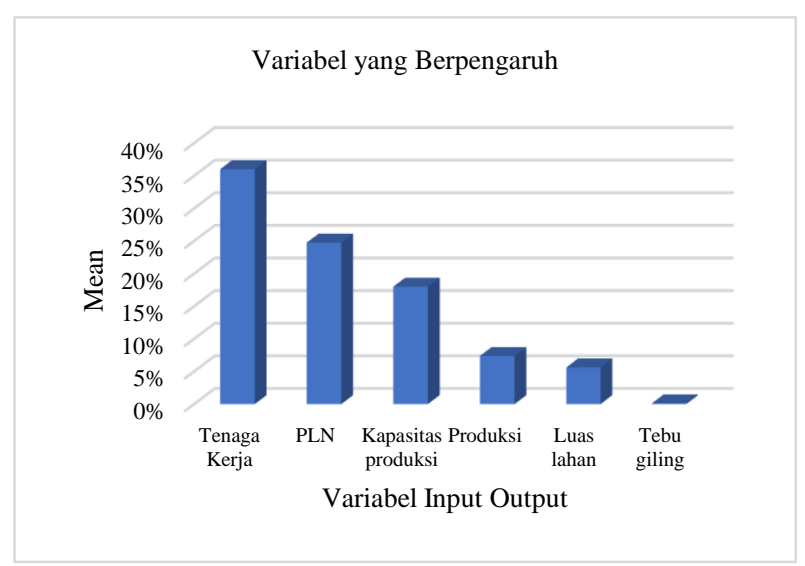

Gambar 3. Variabel yang Berpengaruh terhadap Inefisiensi

yang optimal, Pabrik Gula Purwodadi harus mengurangi luas lahan sebesar 487 ha, mengurangi jumlah kapasitas produksi sebesar 466 ton, mengurangi penggunaan listrik (biaya listrik) sebanyak $1.875 .560 \mathrm{kWh}$, dan mengurangi jumlah tenaga kerja sebanyak 592 orang. Dengan demikian, jumlah produksi Pabrik Gula Purwodadi juga dapat meningkat sebanyak 1.991 ton dari jumlah produksi yang telah dikeluarkan pada tahun ini sebanyak 17.296 ton, sehingga target jumlah produksi yang diharapkan sebesar 19.286 ton.

\section{6) Pabrik Gula Rejosari}

Target perbaikan untuk Pabrik Gula Gending dapat dilihat pada Tabel 11. Pada tahun 2018 nilai efisiensi produksi yang dicapai Pabrik Gula Purwodadi sebesar 0,86. Pabrik gula tersebut mengalami inefisiensi pada input luas lahan, kapasitas produksi, biaya listrik, dan tenaga kerja. Berdasarkan hasil perhitungan target perbaikan, untuk dapat mencapai efisiensi yang optimal, Pabrik Gula Rejosari harus mengurangi luas lahan sebesar 220 ha, mengurangi jumlah kapasitas produksi sebesar 938 ton, mengurangi penggunaan listrik (biaya listrik) sebanyak $1.059 .033 \mathrm{kWh}$, dan mengurangi jumlah tenaga kerja sebanyak 598 orang. Dengan demikian, jumlah produksi Pabrik Gula Rejosari juga dapat meningkat sebanyak 2.449ton dari jumlah produksi yang telah dikeluarkan pada tahun ini sebanyak 14.973 ton, sehingga target jumlah produksi yang diharapkan sebesar 17.422 ton.

\section{7) Pabrik Gula Semboro}

Target perbaikan untuk Pabrik Gula Gending dapat dilihat pada Tabel 12. Pada tahun 2018 nilai efisiensi produksi yang dicapai Pabrik Gula Semboro sebesar 0,99. Pabrik gula tersebut mengalami inefisiensi pada input luas lahan, tebu giling, dan tenaga kerja. Berdasarkan hasil perhitungan target perbaikan, untuk dapat mencapai efisiensi yang optimal, Pabrik Gula Semboro harus mengurangi luas lahan sebesar 1.341 ha, mengurangi jumlah tebu giling sebanyak 9.210 ton, dan mengurangi jumlah tenaga kerja sebanyak 307 orang. Dengan demikian, jumlah produksi Pabrik Gula Semboro juga dapat meningkat sebanyak 533 ton dari jumlah produksi yang telah dikeluarkan pada tahun ini sebanyak 65.627 ton, sehingga target jumlah produksi yang diharapkan sebesar 66.159 ton.

8) Pabrik Gula Sudhono

Target perbaikan untuk Pabrik Gula Gending dapat dilihat pada Tabel 13. Pada tahun 2018 nilai efisiensi produksi yang dicapai Pabrik Gula Sudhono sebesar 0,86. Pabrik gula tersebut mengalami inefisiensi pada input luas lahan, kapasitas produksi, biaya listrik, dan tenaga kerja. Berdasarkan hasil perhitungan target perbaikan, untuk dapat mencapai efisiensi yang optimal, Pabrik Gula Sudhono harus mengurangi luas lahan sebesar 628 ha, mengurangi jumlah kapasitas produksi sebesar 834 ton, mengurangi penggunaan listrik (biaya listrik) sebanyak 1.189.807 kWh, dan mengurangi jumlah tenaga kerja sebanyak 585 orang. Dengan demikian, jumlah produksi Pabrik Gula Sudhono juga dapat meningkat sebanyak 2.674 ton dari jumlah produksi yang telah dikeluarkan pada tahun ini sebanyak 15.906 ton, sehingga target jumlah produksi yang diharapkan sebesar 18.580 ton.

\section{H. Variabel yang Berpengaruh terhadap Inefisiensi}

Penentuan variabel input output yang berpengaruh dan tidak berpengaruh terhadap inefisiensi ditentukan berdasarkan nilai persentase target perbaikan dan nilai mean dari persentase target perbaikan tersebut. Berdasarkan grafik target perbaikan dan mean target perbaikan yang telah dibahas di atas, dapat disimpulkan melalui Gambar 3 di bawah ini dapat diketahui bahwa variabel yang berpengaruh signifikan terhadap inefisiensi pabrik gula PT Perkebunan Nusantara XI adalah variabel tenaga kerja dengan persentase mean sebesar $36 \%$, biaya listrik sebesar 25\%, dan kapasitas produksi $18 \%$. Sedangkan 2 variabel lainnya yang tidak berpengaruh secara signifikan terhadap inefisiensi adalah variabel produksi dengan persentase sebesar 7\%, dan luas lahan sebesar 6\%. Variabel yang tidak berpengaruh terhadap inefisiensi adalah luas lahan.

\section{KESIMPULAN}

Faktor-faktor yang terlibat dalam model pengukuran efisiensi produksi yaitu kondisi existing perusahaan, proses bisnis, proses produksi, dan variabel input output yang digunakan dalam pengukuran efisiensi produksi tersebut. Variabel tersebut terdiri dari luas lahan, tebu giling, kapasitas produksi, biaya listrik, tenaga kerja dan produksi. Berdasarkan hasil perhitungan technical efficiency (TE ${ }_{\mathrm{CRS}}$ ) terdapat 5 pabrik gula PT Perkebunan Nusantara XI yang mencapai tingkat efisiensi optimal (nilai efisiensi 1) terdiri dari Pabrik Gula Pagottan, Panji, Prajekan, , Wonolangan, dan Wringin Anom. Berdasarkan hasil perhitungan technical efficiency (TE $\mathrm{VRS}_{\mathrm{RS}}$ ), terdapat 10 pabrik gula PT Perkebunan Nusantara XI yang mencapai tingkat efisiensi optimal (nilai efisiensi 1) terdiri dari 
Pabrik Gula Gending, Jatiroto, Kedawung, Olean, Pagottan, Panji, Prajekan, Semboro, Wonolangan, dan Wringin Anom. Pabrik gula yang dijadikan sebagai referensi atau acuan untuk pabrik gula yang belum efisien antara lain Pabrik Gula Pagottan, Panji, Prajekan, Wonolangan, dan Wringin Anom. Variabel yang berpengaruh signifikan terhadap inefisiensi pabrik gula PT Perkebunan Nusantara XI adalah variabel tenaga kerja, biaya listrik, dan kapasitas produksi. Dengan menggunakan metode DEA, didapatkan target perbaikan untuk DMU (pabrik gula) yang inefisien

\section{UCAPAN TERIMA KASIH}

Penulis mengucapkan terima kasih kepada PTPN XI yang telah memberikan kesempatan kepada peneliti untuk melakukan penelitian dan pengambilan data di perusahaan tersebut.

\section{DAFTAR PUSTAKA}
[1] S. Deny, "Ekonomi." [Online]. Available: https://www.liputan6.com/bisnis/read/2042901/ri-terancam-jadi- importir-gula-kedua-terbesar-dunia. [Accessed: 24-Apr-2014].

[2] Katadata, "Statistik," $2019 . \quad$ [Online]. Available: https://databoks.katadata.co.id/datapublish/2019/01/09/indonesiaimportir-gula-terbesar-dunia-20172018. [Accessed: 18-Mar-2019].

[3] V. F. Thomas, "Ekonomi," 2019. [Online]. Available: https://tirto.id/produksi-gula-stagnan-hanya-akal-akalan-pemerintahuntuk-impor-dez4.

[4] Direktorat Jendral Perkebunan, "Statistik perkebunan kopi Indonesia 20152017," Jakarta, 2016.

[5] Sekretariat Dewan Gula Indonesia, Rencana Operasional Pemecahan. 2010.

[6] BUMN, "Profil Singkat Perusahaan," 2018. [Online]. Available: http://www.bumn.go.id/ptpn11/halaman/2.

[7] R. Satrianegara, "Berita." [Online]. Available: https://www.cnbcindonesia.com/news/20180329141323-4-9046/kinerjapabrik-gula-tradisional-rendah-ini-buktinya. [Accessed: 23-Mar-2019].

[8] M. D. Hadad, W. Santoso, D. Ilyas, and E. Mardanugraha, "Analisis efisiensi industri perbankan Indonesia: Penggunaan metode nonparametrik data envelopment analysis (DEA)," Res. Pap., vol. 7, no. 5, pp. 1-28, 2003.

[9] M. J. Farrell, "The measurement of productive efficiency," J. R. Stat. Soc. Ser. A, vol. 120, no. 3, pp. 253-281, 1957.

[10] A. F. L. Gaol, "Penerapan Data Envelopment Analysis dalam Pengukuran Efisiensi Retailer Produk Kendaraan Merek Toyota," Institut Teknologi Sepuluh Nopember, 2017.

[11] O. Havrylchyk, "Efficiency of the Polish banking industry: Foreign versus domestic banks," J. Bank. Financ., vol. 30, no. 7, pp. 1975-1996, 2006.

[12] A. Charnes, W. W. Cooper, and E. Rhodes, "Measuring the efficiency of decision making units," Eur. J. Oper. Res., vol. 2, no. 6, pp. 429-444, 1978, doi: 10.1016/0377-2217(78)90138-8. 